\title{
BIRDS OF A HABITAT SPECTRUM IN THE ITIRAPINA SAVANNA, SÃO PAULO, BRAZIL (1982-2003)
}

\author{
WILLIS, E. O. \\ Departamento de Zoologia, Unesp, C.P. 199, CEP 13506-900 Rio Claro, SP, Brazil \\ Correspondence to: Edwin O. Willis, Departamento de Zoologia, Unesp, C.P. 199, \\ CEP 13506-900, Rio Claro, SP, Brazil \\ Received July 7, 2003 - Accepted August 22, 2003 - Distributed November 30, 2004
}

(With 1 figure)

\begin{abstract}
Some 231 birds were recorded on a sandy plateau in central São Paulo, in an area forming a natural "habitat spectrum", from dry or wet grasslands to bushy ones (campo-cerrado) plus gallery scrub, marshes, and low woods. Subtracting 12 species that mostly flew over, and 56 species that seemed to be vagrants or accidental visitors, 163 species were regular (including 14 that center in nearby anthropogenically-modified zones). The 69 in gallery areas are mostly regionally common woodland species, but one southeastern species has disappeared over the years and three northwestern dry-forest species have entered. The 81 grassland species include several rare birds, and hence are important despite exhibiting lower biodiversity than in regional forest areas. Seven rare species disappeared over the years, some due to lack of fires, others because of either recent "greenhouse" dry years or protected vegetation growing to taller campocerrado. Several other species are becoming rare. Low vegetation forms a spectrum of temporally unstable habitats that change rapidly; one needs actively managed large areas and corridors even though many open-area birds can fly long distances to varying habitat patches.
\end{abstract}

Key words: birds, gallery woods, grasslands, habitat spectrum, savannas.

\section{RESUMO}

\section{Aves de um espectro de habitats nos campos de Itirapina,} São Paulo, Brasil (1982-2003)

Cerca de 231 espécies de aves foram registradas em um planalto arenoso no centro do Estado de São Paulo, em uma área formando um "espectro de habitat" natural, que passou de campos secos ou úmidos a arbustivo (campo-cerrado) com brejos, arbustos e mata de galeria baixa. Subtraindo 12 espécies que, no geral, passavam voando e 56 espécies que pareciam vagantes ou visitantes acidentais, 163 espécies são regulares (incluindo 14 que se centralizavam em zonas modificadas pelo homem). Pelo menos 69 das espécies observadas nas matas de galeria são regionalmente comuns nesses locais, mas uma das espécies do sudeste desapareceu ao longo dos anos e 3 espécies do noroeste invadiram essa área. As 81 espécies dos campos incluem várias aves raras e, portanto, são importantes, apesar da baixa biodiversidade em relação às áreas de mata regional. Sete espécies raras desapareceram ao longo dos anos, algumas por causa da falta de queimadas, outras por causa da vegetação protegida crescendo para campo-cerrado mais alto ou por causa do recente "efeito estufa" que proporcionou anos secos. Algumas outras espécies estão se tornando raras. A vegetação baixa forma um espectro de habitats temporariamente instáveis que muda rapidamente. Necessitamos de gerenciamento ativo, de grandes áreas e de corredores, embora muitas aves de áreas abertas possam voar longas distâncias para fragmentos de habitats mutáveis.

Palavras-chave: aves, campos, espectro de habitats, mata ciliar, savanas. 


\section{INTRODUCTION}

Birds of Atlantic forests in Brazil are well known to be endangered by increasing human populations and "show-off" consumers, but loss of species in interior dry forests and grasslands has only recently been reported (Willis \& Oniki, 1988; Parker \& Willis, 1997). Cerrado grasslands of central Brazil have been widely destroyed for agriculture, with the situation especially serious in São Paulo and Paraná states at the southeastern limit of these vegetation types.

In 1982, I started studies of birds of one of the few such native grasslands in São Paulo State, near the town of Itirapina. The zone, located in the central part of the state, lies atop the Chapada of Itirapina, an isolated plateau of sandy soils, causing low grasslands (campos) and grasslands with scattered bushes (campo-cerrado). Gallery woods (matas ciliares) follow the small Itaqueri river and Córrego do Lobo, plus smaller side creeks that start in wet grasslands (banhados), going toward Broa reservoir (a beach-resort), and thence to the rio Jacaré-Guaçu off to the northwest. This wide spectrum of intergrading and temporally varying habitats yields a large variety of birds, reported on several "Christmas Counts" of one day each near the end of every year since 1991 (Willis, 1992 and later).

Here I report on studies made between 1982 to 2003 of birds of these grasslands and gallery woods near a railroad bridge over the Itaqueri river at a point $179.7 \mathrm{~km}$ from São Paulo (at $715 \mathrm{~m}, 22^{\circ} 14$ 'S, $\left.47^{\circ} 52^{\prime} \mathrm{W}\right)$. Off-north gallery forest, cerrado, and eucalyptus have been studied near the town of São Carlos (Motta-Júnior, 1990). Mixed flocks and frugivores have been studied just north, in the Broa cerrado area (Ragusa-Netto, 1997, 2000, 2002; Marcondes-Machado, 2002).

\section{STUDY AREAS AND METHODS}

The study area (Fig. 1) is a natural grassland between pine plantations (east of the Itaqueri) and the gallery wood of the Córrego do Lobo west. The north tip of the area reaches the south end of Broa reservoir, and the south boundary is just south of the paved road from Itirapina west to the town of Brotas. From $\mathrm{km} 179$ to $\mathrm{km} 183$ on the railroad, electric power lines cross the area from east to west. Just north of the railroad, a dirt road goes along the south edge of the Experiment Station of the Instituto Florestal
(IF) of São Paulo. Near km 180, the IF planted a 1$\mathrm{km}$ narrow stretch of eucalyptus years ago, and the flowers attract some birds (Willis, 2002) while the shade helps others. Well $\mathrm{N}$ of $\mathrm{km} \mathrm{182}$, a pine plantation from the early 1980s was cut in 2000-01. This and other plantations give rise to scattered pine trees invading the grasslands. Most such sprouts were cut in the late 1990s, but new ones constantly arise.

As forestry agents want to avoid fires, roads and firebreaks sometimes plowed to $50 \mathrm{~m}$ wide wander through the Experiment Station (now the southern part of an Estação Ecológica or Ecological Station). Some go through wet grasslands, others through dry ones, and still others go off to the north in campo-cerrado zones on slightly higher areas some distance away from patches or stretches of gallery woods and nearby bushy swamplands. Trucks of RIPASA, a Brazilian cellulose and paper company off to the west of Lobo creek, at times use the roads of the Ecological Station to remove cut eucalyptus trees. In 1984 and 1992, a few cows were allowed in (subsequently removed "UNESP" did not remove, they requested removal by the State University of São Paulo at Rio Claro (UNESP) if as interfering with botany studies), and a few horses wander in even now. Weedy stretches unfortunately develop along roads and firebreaks, especially dense Brachiaria and sticky Melinis minutiflora, introduced grasses. Also, because of protection from fire and grazing, the native and introduced grass and bushes have gotten very tall and thick since 1995 .

In this Ecological Station, areas studied were mostly along the railroad. Area B (Fig. 1) with 155 visits (0.5-1 hour each; only 10 from Aug. 1999 on) included gallery woods, bushy marshlands, the eucalyptus stretch, and nearby dry grasslands to $\mathrm{km}$ 180.7 on the railroad. Area C with 169 visits (20, from Aug. 1999 on) was dry grasslands with a few bushes, plus two gallery woods and bushy marshes north of $\mathrm{km} \mathrm{181.7.} \mathrm{Area} \mathrm{E,} \mathrm{with} 165$ visits (27 from Aug. 1999 on), was open grasslands to km 182.7, plus an area of bushy marshes off north. Several wet grasslands, dry in winter (especially in recent dry years) cross Area E. Grasslands and bushy grasslands off north were little studied: Area F near the pine plantation with only 24 visits (mostly 198386 and 1994 on), and Area G near Broa Reservoir only twice (late 1994). As these two areas were only visited after 9 a.m., birds were uncommon unless mixed flocks were encountered. 
South of the railroad are private "farmlands". East of the Itaqueri (Area A, Fig. 1), seminatural bushy pastures, rather like natural burned cerrado, were plowed in 1985-1994 and left bare or planted with low rice, soybeans, or corn. Erosion was great and, even with calcium, chicken dung, and other fertilizers, production low most years. From 1995 on, the area became a treeless cattle pasture, with plantations of coffee and other possibly valuable crops off to the south. A low area with a side gallery wood and wet grasslands, plus the Itaqueri gallery wood and narrow wet grassland, were left. As few birds used the croplands or pastures, I worked mostly along the galleries. Many of my visits of 0.5-1 hours to Area A were early in the day up until June 1991 (47 of 62 visits, versus 10 of 57 later, including two visits from Aug. 1999 on), but with plowing or closed gates, I had to enter westward near Area E, reaching Areas A and B after 9 a.m. or not visiting much (the reasons for fewer records of some gallery-wood birds since 1991).

West of the Itaqueri, a wide wet grassland or grassy marsh was not checked except along the railroad. Beyond, the area rose to campo-cerrado open scrub with areas used by cattle, or burned now and then to form areas still used by rheas and Lesser Nothuras in the 1980s. A small area southward, near $\mathrm{km} 103.5$ on the highway, is owned by Seriema, a sand-mine company (the white sand over this whole prairie is valuable and may yet result in widespread habitat destruction).

This company, after planting some eucalyptus for shade and opening a few marshy pools used by birds near the river, swamped the pools with mud in the late 1980s. With the river muddied from Seriema's operation and the Broa beaches becoming dirty, ecologists joined the tourists to stop the pollution. The company then flushed their dirt into ponds that ate westward into the campo cerrado, in addition to extending their pits westward. An hour or so at dawn (plus 0.5 hour pre-dawn on 31 of the 107 visits) often found me at the highway bridge at $\mathrm{km} 103$ near the sand mine. South of this bridge, and north where the area is not flooded with sand, there are still privately owned low gallery woods and wide wet grasslands. Unfortunately, traffic is now so noisy and busy that I have mostly given this up (1 visit from Aug. 1999 on).

Meanwhile, the bushy grasslands and pastures off west near km 181.5 were bought by SADIA, a chicken-raising company. From 1986 on, they bulldozed large areas, installed big henhouses, and then plowed nearby tracts and started eucalyptus plantations "to provide shade and fire protection". On the Sunday when I saw them starting to plow their last campo-cerrado areas, closer to the railroad (in preparation for planting eucalyptus), in the center of the only area with Lesser Nothuras, I got a television station to report their failure to provide an environmental impact report (RIMA). The company stopped planting, but the damage had been done: Brachiaria invaded plowed tracts, and the cut eucalyptus zone sprouts have come back rapidly every year and been cut only every 2 or 3 years, leaving stalks on the ground. It was during this period that the Lesser Nothura vanished.

West of areas belonging to SADIA, there were already RIPASA eucalyptus plantations along the highway. These unfortunately separated the area considered in this report from a prairie pasture (regarded elsewhere as an Anthus nattereri site) southwest near $\mathrm{km} 106$ on the highway by the upper Lobo. The company decided in 1986 to plant pines north to $\mathrm{km} 183$ on the railroad, replacing bushy natural pastures. My television report caused them to leave a small grassland-banhado zone near $\mathrm{km}$ 182.7 as a natural reserve, though they put in $50 \mathrm{~m}$ wide plowed firebreaks. Just east, a small triangle of private property between RIPASA and SADIA had been seminatural campo pasture, but the owner (with an eye towards putting in horses and, later, open a sand mine) dredged a sand pond. The Instituto Florestal put a stop to the plans for this sand mine, which would have dumped debris downcreek across the railroad into their prairie. The sand piles near the pond were later removed, apparently by thieves with big trucks. In late 1996, a fire started in the abandoned area, which was eventually stopped by neighbors plowing a firebreak across it (private owners seem afraid of fires due to the risk of being fined by Brazilian forestry agencies). A fence was put in near the highway in 1999 (perhaps to stop people from bypassing a new toll booth at $\mathrm{km} 106$ on the highway), blocking my entry to $\mathrm{km} 182.5$ as well. Lately I have entered by the RIPASA office and through eucalyptus

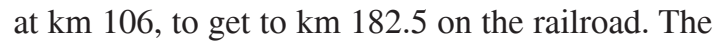
RIPASA, central triangle, and SADIA campo and campo-cerrado remnants in Area D (Fig. 1), were visited for 0.5-1 hour, mostly in late morning, through June 1991 (39 of 61 visits, versus 5 of 86 later.) 
Studies have mostly been of transects, checked from 6 to 12 a.m., rarely in the afternoon or late in the day. I register numbers of individuals, not counting birds seen again while returning along a strip. Ten o'clock in the open areas is sometimes so hot that many birds vanish, though mixed flocks are seen. I sometimes arrive before sunrise, mostly at the $\mathrm{km} 103$ area (above; also 7 times in 199397 at D, plus 30 Oct. and 14 Nov. 2001 at B), to listen for snipes and other night birds.

Hunting and cage-bird activities likely influence censuses of several species. I caught several cagebird trappers in the A area and asked them to leave before I called the forest police, but probably others took their place. Hawk shooting and game-bird hunting, though prohibited, is common in São Paulo. I have seen several dead birds on the highway and found a hawk and several snipes with broken wings under power lines or next to fences. The only state specimen of the rare rail Laterallus xenopterus was on the railroad track at $\mathrm{km} 180$ by the Itaqueri marsh on 1 Nov. 1994 (Oniki \& Willis, 1996).

Several high-rain years have occurred since the big 1982 El Niño, but the region seems to have become dryer ("greenhouse" heating?) since then. The very dry "La Niña" of 1999-2001 ended in late 2002, affecting results gathered near the end of the study (less water in prairie areas and in creek marshes). Winter months are cool and dry, with frost killing tips of gallery trees on 26 June 1994 and perhaps on other occasions ( 2 dead Alopochelidon near burrows on the morning of 12 June 1985, for instance). Fires, mostly in private areas south of the railroad, occurred in 1992-93, 1996, and 2002.

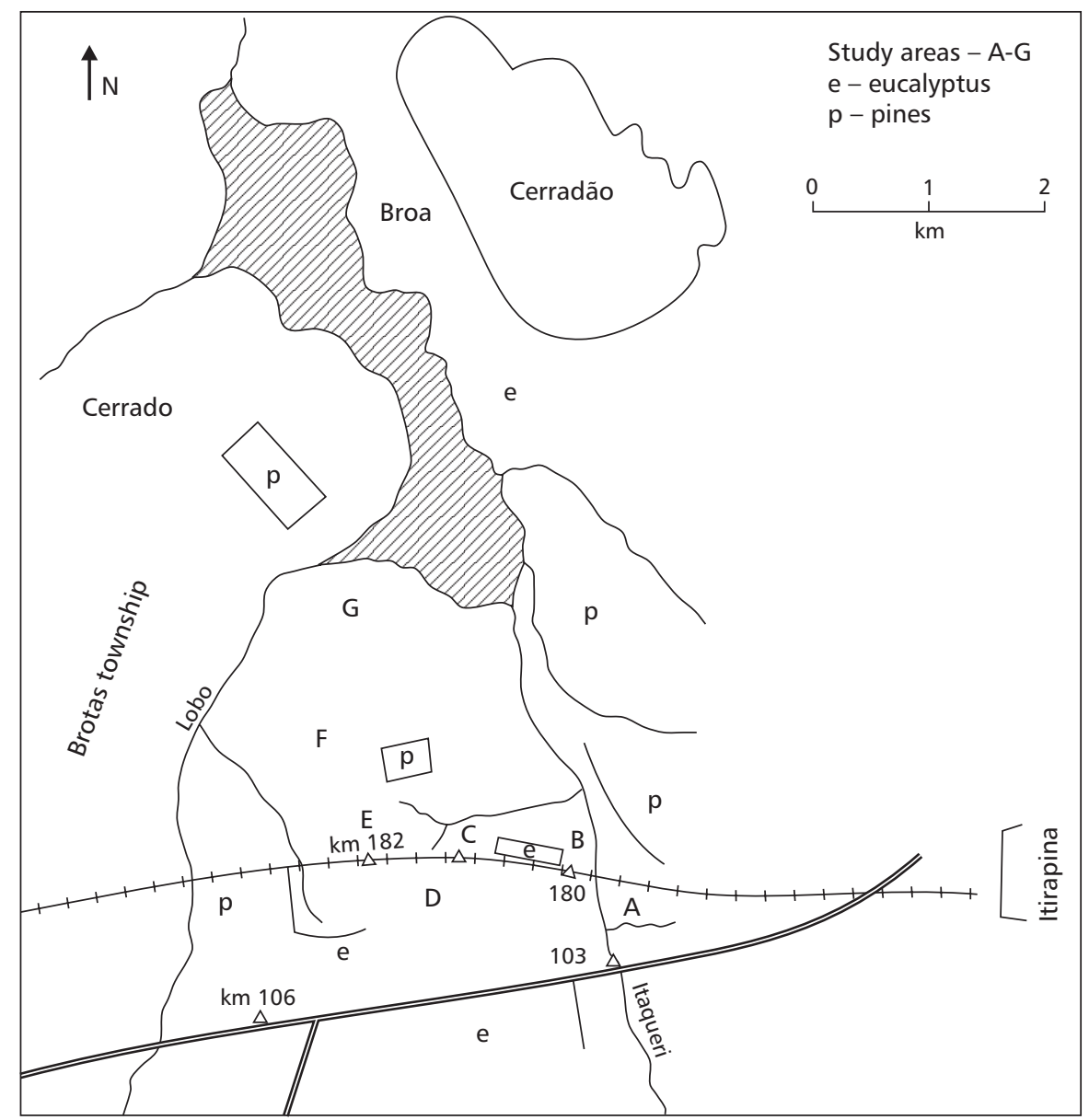

Fig. 1 - Area and subareas (A-G) of study near Itirapina. 


\section{RESULTS AND DISCUSSION}

Some 231 species are recorded from this grassland spectrum, fewer species than in and around a 230 ha semideciduous woodlot off to the southeast, near Rio Claro (Willis \& Oniki, 2002). As in other studies, the forest areas have more species than does the open zone with low vegetation. However, one needs to know if rare species are present, not just the number of species.

Eight of the 231 species were flying past, mostly water birds: Cairina moschata (1 record), Sarkidiornis melanonotus (1 of 3 birds), Theristicus caudatus (1), Platalea ajaja (1), Anhinga anhinga (1 of 2 birds), Phalacrocorax brasilianus (7 of 47), Rostrhamus sociabilis (1), and Brotogeris chiriri ( 3 of 12). Originally, these upland prairies probably had small and fairly permanent ponds; one such still persists in eucalyptus zones $2 \mathrm{~km}$ south up the Itaqueri River. However, the small ponds opened near the sand mine, the large Broa reservoir beachresort, and an artificial pond at the Instituto Florestal in Itirapina rarely have many water birds. Sandy ponds support little water vegetation or fish that are apparently needed by many species. Four other herons mostly fly over without stopping, to larger ponds or (Bubulcus) pastures, and perhaps should also be deducted from the species list (below), which would then number 219 species.

A further 37 species are here considered "vagrants" ("V" species below), some probably local or long-distance summer birds hunting, so far unsuccessfully, for a territory. Six are hummingbirds of more wooded zones, using eucalyptus or other flowers briefly at sites along gallery woods. Dysithamnus mentalis was not recorded in the area but was registered by voice in barely taller woods up the Lobo creek, as were monkeys (Callicebus personatus). Originally the gallery woods may have been taller and contained more forest species. If one subtracts the 37 vagrants, only 182 species seemed birds of the area. Some 19 "A" species were very rare, "accidental" or almost vagrants. If subtracted, only 163 species would really be birds using the area. Some 14 species (plus the 4 herons) center in surrounding habitats (mostly grassy lawns, pastures, roadside lawns, houses, yards, and tree plantations) but these are "peripheral" in this area ("P") and not really birds of grasslands or of low gallery woods. Volatinia and Zonotrichia are rather peripheral too, mostly using seeds of introduced Brachiaria grass. Empidonomus,
Myiarchus tyrannulus, M. swainsoni, and Lathrotriccus straggle in from native woods or tall cerrado in the region, and are peripheral birds in another sense.

Probably not nesting in grassland or gallery woods (though they forage there) but in distant marshy zones (Amazonetta), taller trees outside the area, or behind distant waterfalls, are a number of species discussed below: Tigrisoma, Syrigma, Milvago, 3 swifts, Progne chalybea, and Notiochelidon. Others are migrants ("M") that only spend part of the year here (Tringa, Bartramia, Buteo swainsoni, Hirundo, and Petrochelidon are passage migrants, "N", from North America). Several species occur only or mostly in the summer ("S"). Only "accidental" Asio (Nov.Feb., however, as nests in winter) and Sicalis luteoviridis, in addition to "vagrant" Pyrocephalus seem to be winter birds from the south ("W"). Thus, the area is not a winter zone for any regular species. I have elsewhere suggested (Willis, 2003) that a species remaining only $50 \%$ (or $10 \%$ ) of the year be counted as " 0.5 species" (or " 0.1 species") rather than as a full species, since it occupies other habitats part of the time. This would avoid listing birds that come from other habitats, among species that really occupy the area throughout both day and year.

\section{Gallery birds}

At least 69 species are gallery-woods birds or live in bushy or marshy borders there ("Y" below). Probably there are more gallery birds than grassland ones, but due to their greater habitat height and complexity, gallery woods could not be checked very carefully. One rather rare nesting species, Serpophaga nigricans, went locally extinct at $\mathrm{km} 103$ during the study. Like the extirpated Anumbius of grasslands (below), it is commoner far off to the south, or at high elevations, and was already rare at the start of the study. Several other species were not detected recently, especially from 1996 on, because of difficulty in reaching the gallery woods early in the day (later on, birds are quiet or hide in the shade in this hot, open area), as well as lack of paths in this habitat. Lower numbers of several species (herons, kingfishers, rails, furnariids, kiskadees, swallows, tanagers) could be due to dryer years recently. As noted above, several "vagrant" or "accidental" species visit gallery woods, and seem not to settle because the local woods are too low or small. Frost killing treetops in winter may keep the woods too low and dense, in addition to occasional floods in summer and fires in winter. 
Three uncommon species have recently invaded the gallery zones: Taraba, Schistochlamys melanopis, and Sporophila leucoptera, apparently from dryer forests or warmer regions off to the north and west. The only species endemic to this sort of habitat are Antilophia and Basileuterus leucophrys, both regular in gallery woods of savanna zones off to the north and west in central Brazil. Antilophia extends to creek woods in semideciduous plateau forests off south as well, but in low numbers and with hybrids with Chiroxiphia caudata indicating reproductive problems. B. leucophrys has seemed rare in the last two years, so perhaps gallery woods are drying out.

Interestingly, almost none of the 69 gallery birds are rare in São Paulo State, contrasting strongly with the 81 grassland species. Thus, similar numbers of species in two habitats or large numbers of species do not indicate conservation importance; one has to check each species to see how many localities it inhabits in the state or in southeastern Brazil (Willis, 2000) in order to judge if there are rare species present or just common birds.

\section{Grassland birds}

Some 81 species are grassland, banhado, or campo-cerrado birds ("G"), plus several accidental or vagrant species. Several of these species are rare and included on endangered lists of various types. Unfortunately, 7 species have disappeared from the area in recent years: Nothura minor, Micropygia (absent before 1989), Anumbius, Geositta, Anthus nattereri, Charitospiza, and Coryphaspiza. A. nattereri, present only on grazed but natural " $\mathrm{D}$ " banhado survived, but only in small numbers, until 2000 near a banhado in a natural pasture off SW. Probably lack of burned or semi-grazed natural areas led to loss of ground-feeding Anumbius, Geositta, A. nattereri, and Charitospiza. Rhea and Nothura minor were lost with use of private areas for hen-houses and eucalyptus, but the former species is still present off $\mathrm{N}$ near Broa, and returned in small numbers in areas $\mathrm{C}$ to $\mathrm{E}$ in 2002. Micropygia moved in to areas $\mathrm{C}$ to $\mathrm{F}$ but then disappeared, perhaps with weed growth after fire protection, or because of very dry years (but the species rarely uses wet grassland). Other grassland species have become uncommon recently, for instance six rare migrating Sporophila seedeaters; Gubernetes; a hummingbird; two snipes of wet grasslands; two hunted tinamous; two hawks; an owl (more common in temperate zones); and a crescent-chest. Three swifts have almost disappeared in the region, probably due to ecotourist presence near waterfalls on the border of the Chapada of Itirapina near Brotas.

Several Itirapina grassland species are rare in São Paulo and regionally: Laterallus xenopterus, Polytmus guainumbi, Melanopareia torquata, Alectrurus tricolor, Culicivora caudacuta, Polystictus pectoralis (Parker \& Willis, 1997), Cypsnagra hirundinacea, Neothraupis fasciata, and 7 species of Sporophila. Ornithologists visit from North America and Europe to see these birds. More common in the state, but uncommon recently with loss of habitat, are Rhynchotus rufescens, Gallinago undulata, Gubernetes yetapa, and Emberizoides ypiranganus (the last three in wet grasslands, such as the Laterallus and 5 migrant Sporophila).

Higher numbers of certain species in this savanna recently (Crypturellus, snake-eating Herpetotheres, Synallaxis spp., Cypsnagra, Saltator atricollis) could be due to denser grass and more bushes with fire protection. Many other birds decreased with high grass (Vanellus, Elanus, Buteo albicaudatus, Columbina talpacoti, Guira, Colibri, Colaptes campestris, Furnarius, Melanopareia, Xolmis cinereus, Anthus spp., Ammodramus, icterids) or with dry years (Amazonetta, Gallinago spp., Gubernetes, Tyrannus spp., swallows, Coryphaspiza).

An interesting situation results from the local encounter between Thamnophilus ruficapillus of southern and montane bushy grasslands (including low second growth of old pastures) and $T$. torquatus of bushy cerrado from this area northward. These two species have the same song and often are not seen in the field, which precludes identifying, among other things, whether they form mixed pairs or inhabit interspecific territories. T. torquatus is disappearing in the whole region, perhaps due to destruction or growth (dense bushes, not burned occasionally) of semi-open cerrados.

\section{Species list}

The following list of 223 species does not include 8 birds (above) that were only seen flying past, instead of stopping or foraging. Four herons that rarely stop are included, however. Five numbers for each species below (16/3/0/0/6 for Rhea americana, for instance) give numbers encountered in the following periods: 43 visits of 209.1 hours, 17 June 1982 to 29 June 1987; 41 visits of 219.7 hours, 
19 Aug. 1987 to 14 June 1991; 41 visits of 212.9 hours, 11 Aug. 1991 to 26 June 1994; 43 visits of 211.0 hours, 16 Oct. 1994 to 18 July 1999; 32 visits of 92.6 hours, 29 Aug. 1999 to 16 June 2003. As there were fewer visits and hours in the last period, numbers should be multiplied by around 2 to be reasonably comparable to numbers for the first four periods. Letters are explained above. Rhea americana $\mathrm{G}, 16 /$ 3/0/0/6; Rhynchotus rufescens G, 48/42/62/23/3; Nothura maculosa G, 140/137/67/50/10; N. minor G, 24/39/0/0/0 (last, 22 April 1990); Crypturellus parvirostris G, 2/7/31/27/8 (first 5 Feb. 1987).

Amazonetta brasiliensis G, 184/93/37/45/13; Dendrocygna viduata A, 0/4/4/0/0; Ardea alba, 61/ 16/33/16/11; Egretta thula, 50/20/21/9/0; Bubulcus ibis, 0/0/737/3231/648 (flocks to distant pastures, as 800 on 16 April and 700 on 8 Oct. 1995); Butorides striata Y, 18/26/16/10/0; Syrigma sibilatrix G, 42/53/35/55/20; Nycticorax nycticorax, 16/1/1/ 1/0; Tigrisoma lineatum Y, 3/4/2/1/0; Mesembrinibis cayennensis $\mathrm{Y}, 12 / 3 / 6 / 1 / 0$; Tachybaptus dominicus A, 2/0/0/0/0; Tringa solitaria AN, 1/0/0/0/0 (28 Dec. 1986, as preceding species); Bartramia longicauda AN, 0/2/0/0/0 (10 Dec. 1989, 17 Feb. 1991); Gallinago undulata G, 19/28/12/17/1; G. paraguaie G, 11/6/2/0/0; Jacana jacana A, 1/2/0/0/0; Vanellus chilensis G, 129/271/105/74/27; Aramides cajanea Y, 0/0/3/5/0; Amaurolimnas concolor Y, 0/0/0/0/ 1 (30 Oct. 2001); Rallus nigricans Y, 37/41/29/13/ 6; Porzana albicollis G, 125/98/101/82/50; Laterallus cf. xenopterus G, 2/0/10/7/2; Micropygia schomburgkii G, 0/10/84/97/0 (only from 25 June 1989 to 17 Dec. 1994); Gallinula chloropus V, 1/ 0/0/0/0; Porphyrula martinica V, 0/1/0/0/0; Cariama cristata G, 65/81/73/69/35.

Coragyps atratus P, 124/119/126/97/563 (SADIA dumps in 2001-3); Cathartes aura A, 0/ 4/1/2/4; Elanus leucurus G, 12/22/41/39/0; Leptodon cayanensis V, 0/1/0/1/0 (24 Oct. 1988, 17 Dec. 1996); Chondrohierax uncinatus MY, 2/6/0/2/0 (Oct.-Dec., soars gallery woods 10 am on); Accipiter striatus Y, 3/4/1/2/1; Buteo swainsoni AN, 0/3/1/ 0/0 (24 Nov. 1989, 28 Oct. 1991); B. albicaudatus G, 36/27/13/12/9; B. magnirostris $\mathrm{P}, 48 / 45 / 27 / 64 /$ 23; Buteogallus meridionalis G, 29/15/12/16/7; Milvago chimachima G, 33/39/54/44/24; Caracara plancus G, 137/150/125/106/54; Herpetotheres cachinnans $\mathrm{P}, 1 / 3 / 7 / 7 / 10$; Falco sparverius $\mathrm{G}, 51 /$ 30/39/58/39; F. femoralis G,40/49/43/26/17.
Columba picazuro P, 262/410/333/222/433; C. cayennensis Y, 110/228/314/101/28;

Zenaida auriculata G, 529/778/451/816/224; Columbina talpacoti G, 312/281/258/58/41; C. squammata $\mathrm{P}, 13 / 11 / 0 / 2 / 1$; Leptotila verreauxi $\mathrm{Y}$, 47/32/15/16/20; Coccyzus melacoryphus AS, 0/0/ 0/2/1 (Dec.); Piaya cayana Y, 1/2/4/4/1; Tapera naevia $\mathrm{Y}, 15 / 23 / 15 / 22 / 11$; Crotophaga ani $\mathrm{G} 71 /$ 126/106/115/50; Guira guira P, 2/35/15/26/0; Aratinga leucophthalmus P, 163/176/1219/267/54 (roosted in nearby eucalyptus, more in 1992); Amazona aestiva V, 0/0/2/0/0 (12 Nov. 1993).

Tyto alba A, 0/0/0/1/0; Asio flammeus AG, 0/ 0/0/4/0 (Nov.-Feb. 1994-1997); Rhinoptynx clamator V, 0/0/1/0/0; Athene cunicularia G, 39/66/99/204/ 33; Nyctidromus albicollis V, 1/0/0/0/0; Podager nacunda V, 0/0/0/1/0 (burn, 17 Dec. 1996); Caprimulgus parvulus PS, 3/0/2/1/0 (21 Sept.-6 Nov.); Hydropsalis torquata $\mathrm{G}, 2 / 0 / 1 / 0 / 5$.

Streptoprocne zonaris G, 6/42/36/25/0 (last flock, 1 Nov. 1994); Cypseloides senex GS, 5/11/ 8/18/0 (16 Oct. to 7 Apr.; last, 13 Nov. 1994); $C$. fumigatus GS, 54/6/8/3/1 (5 Oct. to 23 Feb., last ones, 17 Dec. 1996 and 5 Oct. 2002); Phaethornis pretrei $\mathrm{Y}, 1 / 3 / 1 / 0 / 0$; Hylocharis chrysura $\mathrm{Y}, 7 / 30 /$ 31/24/7; Amazilia lactea V, 1/2/1/1/2; Chlorostilbon aureoventris Y, 9/3/8/19/2; Eupetomena macroura Y, 89/107/167/120/28; Colibri serrirostris G, 143/ $288 / 211 / 116 / 27$ (sings in winter, many in Rechsteineria after fire, see Willis, 2002); Polytmus guainumbi GS, 13/19/24/18/2 (25 Sept. to 2 May); Leucochloris albicollis VW, 0/0/1/0/0 (24 May 1992); Melanotrochilus fuscus V, 1/1/3/1/0 (AprilSept.); Aphantochroa cirrochloris V, 0/0/1/0/0 (1 Jan. 1992); Anthracothorax nigricollis VS, 0/0/1/ 0/0 (5 Nov. 1993); Calliphlox amethystina V, 0/0/ 1/0/0 (5 April 1992).

Ceryle torquatus Y, 15/6/8/6/2; Chloroceryle amazona Y, 23/31/27/7/0; C. americana Y, 2/4/4/0/ 0; Bucco chacuru G, 15/2/9/14/12; Ramphastos toco V, 0/0/0/2/0 (pair, 13 Sept. 1998); Picumnus albosquamatus Y, 27/18/17/10/4; Colaptes campestris G, 235/254/206/174/82; C. melanochloros Y, 23/23/ 6/14/1; Melanerpes candidus P, 43/55/64/40/17; Veniliornis passerinus Y, 14/3/3/5/7; Dryocopus lineatus $\mathrm{V}, 0 / 0 / 1 / 0 / 1$.

Lepidocolaptes angustirostris V, 0/1/0/0/0 (27 Aug. 1989); Dendrocolaptes platyrostris V, 1/0/0/ 0/0 (5 Oct. 1986); Geositta poiciloptera G, 10/3/0/ 
0/0 (last 3 and nest in armadillo burrow, 29 June 1987); Furnarius rufus G, 60/88/87/77/22; Anumbius annumbi G, 8/0/0/0/0 (last, 1 Dec. 1985); Phacellodomus ferrugineigula Y, 76/64/64/37/7; Certhiaxis vulpinus Y, 51/45/32/13/0; C. cinnamomeus $\mathrm{Y}, 109 / 66 / 13 / 2 / 4$; Synallaxis spixi G, 26/30/42/36/29; S. albescens G, 47/97/164/267/80 (more with dense grass after fires ended); $S$. frontalis Y 0/0/0/0/1 (7 July 2002); Taraba major Y, 0/1/0/ 1/3 (25 Sept. 1988 on); Thamnophilus doliatus Y, 73/42/77/51/11; Thamnophilus torquatus and T. ruficapillus G, G, 2/26/31/33/18; Thamnophilus caerulescens $\mathrm{Y}, 0 / 0 / 1 / 1 / 3$; Formicivora rufa $\mathrm{G}, 17 /$ 1/0/4/12; Conopophaga lineata Y, 18/12/7/8/0; Melanopareia torquata G, 112/110/107/242/40 (more in dense grass after fires ended, but dropped off later).

Xolmis cinereus G, 136/130/104/91/11 (less with dense grass); X. velatus G, 98/92/98/102/50; Fluvicola pica $\mathrm{V}, 2 / 0 / 0 / 0 / 0$ (male building nest Dec.-Feb. 198687); F. leucocephala Y, 53/8/0/0/1; Colonia colonus V, 1/1/0/0/0 (Aug. 1986 and 1989); Pyrocephalus rubinus VW, 0/1/1/0/0 (April 1991, 1994); Knipolegus cyanirostris VW, 1/0/0/0/0 (17 June 1987); Alectrurus tricolor G, 89/96/138/201/51; Hirundinea ferruginea V, 0/3/0/0/0 (Sept.-Nov. 1988); Culicivora caudacuta G, 0/15/63/118/46 (first pair, 19 Aug. 1987); Polystictus pectoralis G, 62/74/88/136/33; Suiriri suiriri A, 7/1/1/0/0; Satrapa icterophrys Y, 64/45/ 20/13/0; Gubernetes yetapa G, 116/135/142/88/41; Serpophaga subcristata Y, 33/54/35/22/13; S. nigricans $\mathrm{Y}, 33 / 9 / 0 / 0 / 0$ (last 15 Nov. 89); Elaenia obscura Y, 81/54/73/50/24; E. flavogaster Y, 157/ 165/214/130/67; E. chiriquensis GS, 102/88/135/84/ 32 (27 Aug.-22 April); E. mesoleuca MY, 7/2/10/1/ 2 (Oct.-Nov. and early May); E. parvirostris MY, 3/ 0/3/0/1 (Sept.-Nov.); Camptostoma obsoletum Y, 52/ 39/46/37/23; Myiophobus fasciatus Y, 153/142/184/ 145/40; Todirostrum cinereum Y, 57/57/41/30/9; T. poliocephalum A, 2/0/0/0/0 (25 May and 3 Aug. 1986); Lathrothriccus euleri $\mathrm{Y}, 0 / 0 / 2 / 3 / 1$ (21 Sept. to 4 Dec., migrants?); Cnemotriccus bimaculatus V, 0/0/0/1/1 (Oct. 1994 and 2001); Myiarchus ferox $\mathrm{Y}$, 39/36/47/35/19; M. tyrannulus A, 2/2/6/0/1 (21 Aug. to 11 Nov.), M. swainsoni SY, 0/0/0/10/0 (27 Oct. to 20 Dec., migrants?); Machetornis rixosa $\mathrm{P}, 19 /$ 7/3/5/4; Tyrannus savana SY, 169/156/161/87/43 (19 Aug. to 2 Feb.); T. melancholicus SY, 175/165/171/ 144/66 (8 Sept. to 28 Apr.; twice in June; once in Aug.); Pitangus sulphuratus Y, 170/141/76/57/7; Megarynchus pitangua $\mathrm{V}, 0 / 2 / 1 / 1 / 0$ (Oct.-Nov.); Myiozetetes similis V, 0/0/1/0/0 (20 June 1993);
Empidonomus varius SY, 5/5/2/4/2 (21 Sept. to 15 Nov. mostly); Antilophia galeata Y, 6/17/18/4/3.

Progne tapera GM, 27/3/4/0/0 (Oct.-Nov., March-June); P. chalybea G, 16/43/10/30/44 (mostly in summer); Notiochelidon cyanoleuca P, 32/167/ 128/87/34 (more with SADIA hen-houses); Tachycineta leucorrhoa Y, 148/220/128/96/35; Stelgidopteryx ruficollis Y, 221/156/115/91/44; Alopochelidon fucata G, 549/773/891/468/169; Hirundo rustica GN, 27/3/10/7/0 (8 Sept.-Nov. and March); Petrochelidon pyrrhonota GN, 65/42/864/ 6/0 (late Oct.-Dec., notably 500 on 9 Nov. and 350 on 15 Nov. 1992 with rain storms).

Cyanocorax chrysops V, 0/0/3/3/3; C. cristatellus G, 113/86/86/92/48; Troglodytes aedon Y, 29/54/47/45/13; Donacobius atricapilla Y, 12/ 39/34/3/0 (last on 6 Nov. 1994, 29 Oct. 1997); Mimus saturninus G, 170/261/292/289/144; Turdus leucomelas $\mathrm{Y}, 53 / 36 / 35 / 23 / 14 ;$ T. amaurochalinus $\mathrm{Y}, 124 / 69 / 72 / 45 / 11 ;$ T. rufiventris $\mathrm{Y}, 0 / 1 / 12 / 12 / 5$; Anthus lutescens G, 9/58/17/0/0; A. nattereri G, 12/ 2/0/0/0 (last on 1 Nov. 1988); Cyclarhis gujanensis Y, 31/33/67/50/25; Vireo olivaceus SY, 4/2/0/4/0 (Sept.-Nov.); Hylophilus amaurocephalus Y, 5/2/ 2/2/0; Passer domesticus V, 0/4/1/0/0; Carduelis magellanica A, 0/0/0/0/3 (14 Nov. 2001).

Geothlypis aequinoctialis G, 149/150/172/110/ 58; Parula pitiayumi Y, 35/29/18/16/2; Basileuterus leucophrys Y, 36/25/34/37/8; B. hypoleucus V, 0/ 0/1/0/3; Dacnis cayana V, 0/2/2/2/2; Thlypopsis sordida Y, 6/12/1/10/2; Euphonia chlorotica Y, 6/9/ 15/2/0; Piranga flava P, 0/8/3/4/3; Nemosia pileata V, 0/0/2/0/0 (20 Sept. 1992); Pipraeidea melanonota VW, 1/0/0/0/0 (14 June 1984); Tangara cayana Y, 77/90/89/67/15; Thraupis sayaca Y, 155/193/193/ 132/27; Ramphocelus carbo Y, 53/15/39/33/7; Tachyphonus coronatus V, 1/0/0/0/0 (1 Feb. 1987); Cypsnagra hirundinacea G, 60/52/80/130/88; Neothraupis fasciata G, 107/193/179/192/48; Paroaria coronata V, 1/0/0/0/0 (28 Dec. 1986, flying up the Itaqueri); Schistochlamys melanopis Y, 0/ 0/0/2/5 (two from 13 Sept. 1998 on); S. ruficapilla Y, 7/12/10/34/9; Saltator similis V, 0/2/0/0/0 (21 May and 29 Oct. 1989); S. atricollis G, 10/9/22/ 54/81; Charitospiza eucosma G, 8/2/0/0/0 (last two, 28 Feb. 1988); Coryphospingus cucullatus A, 6/ 1/0/0/1; Sicalis citrina G, 87/169/315/152/112; S. flaveola V, 1/0/0/0/0 (27 Sept. 1985); S. luteoviridis AW, 0/0/10/0/0 (flock, 29 Apr. 1992); Volatinia jacarina, 298/756/987/711/317; Sporophila caerulescens GM, 325/452/212/168/68; S. nigricollis 
VM, 0/2/0/0/0 (27 Nov. 1988, 9 Jan. 1989); $S$. plumbea GM, 0/1/3/0/2 (yellow-billed form; winter, two, 7 July 2002); S. bouvreuil GS, 28/210/207/ $240 / 109$ (9 Oct. to 2 May); S. hypoxantha GM, 14/ 56/20/19/6; S. palustris GM, 0/2/4/1/0; $S$. melanogaster GM, 11/49/12/13/1; S. ruficollis GM, 0/1/0/0/0; S. cinnamomea GM, 0/2/1/0/0; S. lineola PS, 5/0/2/0/7 (13 Nov. to 20 Dec., rare to $7 \mathrm{Feb}$.); $S$. leucoptera $\mathrm{Y}, 20 / 38 / 35 / 21 / 9 ;$ Oryzoborus angolensis A, 0/0/3/0/0; Passerina brissoni A, 0/0/1/0/1; Coryphaspiza melanotis G, 58/62/46/50/1 (last 29 Aug. 1999); Emberizoides herbicola G, 418/384/532/601/ 251; E. ypiranganus G, 52/41/43/37/28; Ammodramus humeralis G, 466/454/494/536/164; Zonotrichia capensis G, 229/283/227/303/168; Molothrus bonariensis $\mathrm{P}, 32 / 52 / 20 / 30 / 3$; Pseudoleistes guirahuro G, 237/293/394/299/90; Sturnella superciliaris GS, 19/ 27/5/7/1; Icterus cayanensis V, 0/1/0/0/0 (8 Oct. 1989); Gnorimopsar chopi A, 2/0/0/0/0 (8 Sept. 1985).

\section{General comments}

Maps of São Paulo vegetation put out by the Instituto Florestal (1993) leave this whole instituteowned study area (except for planted forests and gallery woods) blank, as if it were agricultural land. These maps are based on satellite photos, which distinguish neither native grasslands from pastures nor those areas marked for preservation.

Local people and new residents are exploiting private areas in this region more and more and, despite poor soils, planting oranges or other crops, cutting eucalyptus and pine trees every few years, mining white sand, cleaning wide strips along the highway and firebreaks, and putting in beach homes near the Broa Reservoir. The Instituto Florestal planted much of the Itirapina region with pines years ago. Recently, off in the distance, tourists flock around the waterfalls, flying their helicopters, going rafting, and paying no attention to nesting swifts or vultures (including King Vultures, Sarcorhamphus papa) along the cliffs. They do not even keep sewage out of the up-to-now fairly clean rivers.

Fires, natural in cerrados and preventing dense weeds and cerradão woodlands from taking over, are now blocked by forest police, and by companies that plant eucalyptus. Foresters are rarely familiar with recent studies of disastrous fires in protected U. S. forests and prairies, or that lack of fires causes invasion of foreign weeds and bushes. Native cerrado bushes are "cleaned" out of cow pastures and
Brachiaria is introduced, which is one of several species (including even pine trees) invading native grasslands wherever one plows a firebreak or creates an edge. Dry years are more frequent recently, either as part of a natural cycle or a result of greenhouse effects.

The grassland species sometimes range into pastures and town edges, but other species are rare and limited to natural habitats. Loss of 7 such species over the study indicates serious problems, as these species often lack habitats in São Paulo State, and recolonization would be difficult. The rare nightjar Caprimulgus candicans may once have occurred here, as Natterer collected it in the early 1800s in similar zones some $95 \mathrm{~km}$ off to the northeast. Some rare species depend on recently burned habitats, others on unburned weedy ones, so local fires every few years should be better than the present policy of complete fire suppression and wide firebreaks. Control of hunters and cage-bird captures is needed. Gallery forests are not often home to rare species, and in general are protected even on private lands. And sand mines, of course, can cause future problems.

Easily polluted water supplies are not too damaging for birds here because sandy lakes have little aquatic vegetation. Heron colonies appear in the region now and then, killing the gallery woods with feces for a time, especially since abundant Bubulcus ibis moved into São Paulo after 1980 (these birds use pastures, not sterile water areas). The only endangered water birds in the region are a few grassland species, such as Syrigma, snipes, Laterallus, Micropygia, and Gubernetes.

Perhaps migrant Numenius borealis once stopped here (as in similar areas off to the south near Ipanema, collected by J. Natterer in the early 1800 s), but it is now probably extinct. Migrant Bartramia might move in if fires were allowed. Though not recorded for the present grassland ponds, winter Porphyriops melanops (rather rare in São Paulo) did use a natural pond upriver. Other winter species rarely use grasslands or gallery woods here, but six rare migrant Sporophila that pass through going south in the spring are certainly important. An extinct form of Sporophila bouvreuil once occupied grassland areas now covered by the São Paulo airport, and several of the rare species in my study once lived in the Ipiranga grasslands, now incorporated into the city of São Paulo; however, these were not preserved. Use of the zone by migrant North American Pet trochelidon and Hirundo going 
south is not obviously important, as both can even use cane fields as long as a water supply is nearby.

A major problem with preserving these open habitats is variable "spectral" diversity of habitat types over time and space, a factor rarely noted for forest birds (but probably important there too). Authors outside the tropics often report bird cycles based on cold, drought, and other factors affecting birds in low vegetation or simple woods, but in the tropics habitats are often considered "constant". Low or simple habitats are especially likely to vary over time, as these have few small plant species that can die off given a few years of drought or rains, cold or heat, fires or insects (destroying all, instead of certain parts, of the habitat). One small or even medium patch is not enough unless nearby sites provide "transfer zones" for the spectrum of habitats, changing up and down various scales.

Several Itirapina species have increased in numbers in areas of recent fires; others have done so in areas that have not burned. Still others have increased in numbers in successive wet, or dry years, moving to more humid or dry areas at other periods in the climatic cycles. Cycles of abundance and rarity occur for unknown reasons in other cases, so protected areas may need to be varied, as well as large or connected, to preserve many species over time. Birds that have to move around to find habitats over time need even larger and more varied natural reserves than do birds in tall vegetation, where trees help to maintain local humidity.

While open-area birds should be able to move about better than do closed-forest birds, even those passing over forests and cities or agricultural areas, it is not wise to separate open habitats by dozens of kilometers. Traveling birds lose energy, or can be predated. Corridors of natural open vegetation could be established, from Itirapina north to central Brazil, to reestablish lost species like the firedependent Geositta. Local fires, like the one in 2002 off north near the Broa airport and another near Seriema, have not resulted in reestablishment of lost species, probably due to the small areas of open vegetation and lack of nearby populations.

Open-vegetation "spectra" in the Itirapina region are being destroyed rapidly, and where preserved tend to grow to cerradão. Climate changes, whether or not caused by greenhouse warming (possible in the losses of Anumbius and Serpophaga nigricans, southern cold-region birds, see above), generate local fluctuations that make even large preserved areas lose species, indicating the need for larger and diversified reserves. Off to the northeast, near Broa and São Carlos, open habitats are often destroyed or turned into Brachiaria by settlers or cattle ranchers. In any case, the condition of "vegetation spectra" or "spectral reserves" is certainly critical, and difficult to manage.

Acknowledgements - I thank CNPq for help with part of the study, the Instituto Florestal and local owners for permission to study on their properties, and several students for field help. Yoshika Oniki helped with writing. Publication n. 38 of the Institute for Studies of Nature.

\section{REFERENCES}

INSTITUTO FLORESTAL, 1993, Inventário florestal do Estado de São Paulo. Instituto Florestal, São Paulo, 199p.

MARCONDES-MACHADO, L. O., 2002, Comportamento alimentar de aves em Miconia rubiginosa (Melastomataceae) em fragmento de cerrado, São Paulo. Iheringia, Sér. Zool., 92: 100 .

MOTTA-JÚNIOR, J. C., 1990, Estrutura trófica e composição das avifaunas de três habitats terrestres na região central do estado de São Paulo. Ararajuba, 1: 65-71.

ONIKI, Y. \& WILLIS, E. O., 1996, Morte acidental em aves comuns por fatores humanos. Rev. Cent. Ci. Bioméd., Univ. Fed. Uberlândia, 12: 33-37.

PARKER, T. A. III \& WILLIS, E. O., 1997, Notes on three tiny grassland flycatchers, with comments on the disappearance of South American fire-diversified savannas. Ornithol. Monogr., 48: 549-55.

RAGUSA-NETTO, J., 1997, Seasonal variation in foraging behavior of Cypsnagra hirundinacea in the campo-cerrado. Ararajuba, 5: 72-75.

RAGUSA-NETTO, J., 2000, Raptors and "campo-cerrado" bird mixed flocks led by Cypsnagra hirundinacea (Emberizidae: Thraupinae). Rev. Bras. Biol., 60: 461-467.

RAGUSA-NETTO, J., 2002, Vigilance toward raptors by nuclear species in bird mixed flocks in a Brazilian savannah. Studies Neotr. Fauna Env., 37: 219-226.

WILLIS, E. O., 1992, Itirapina, São Paulo, Brazil (Christmas Count). American Birds, 46: 1021.

WILLIS, E. O., 2000, Ranking urban avifaunas (aves) by number of localities per species in São Paulo, Brazil. Iheringia, Sér. Zool., 88: 139-146.

WILLIS, E. O., 2002, Birds at Eucalyptus and other flowers in southern Brazil: a review. Ararajuba, 10: 43-66.

WILLIS, E. O., 2003, Birds of a eucalyptus woodlot in interior São Paulo. Braz. J. Biol., 63: 141-158.

WILLIS, E. O. \& ONIKI, Y., 1988, Bird conservation in open vegetation of São Paulo, Brazil, pp. 67-70. In: P. D. Goriup (ed.), Ecology and Conservation of Grassland Birds. ICBP Technical Publ. 7, Cambridge, England.

WILLIS, E. O. \& ONIKI, Y., 2002, Birds of a central São Paulo woodlot: 1. Censuses 1982-2000. Braz. J. Biol., 62: 197-210. 